\title{
Resenha
}

\section{A mise em scène no cinema: do clássico ao cinema de fluxo}

\section{EMILIANO CUNHA}

Mestre em Comunicação pelo PPGCom da Pontifícia Universidade Católica do Rio Grande do Sul (PUCRS).

<emilfc@gmail.com>

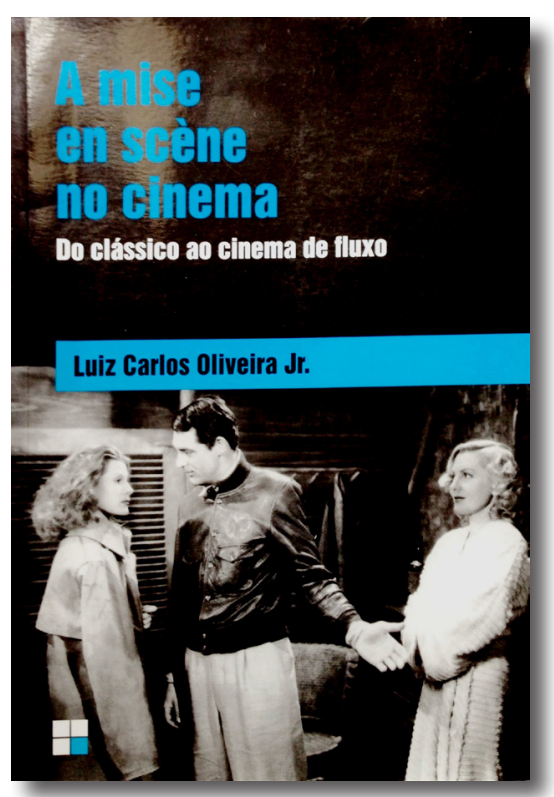

RESENHA DE:

OLIVEIRA JUNIOR, Luiz Carlos.

A mise em scène no cinema: do clássico ao cinema de fluxo.

Campinas: Papirus, 2013.

Pesultado da pesquisa realizada para uma dissertação de Lmestrado, A mise em scène no cinema: do clássico ao cinema de fluxo (2013), de Luiz Carlos Oliveira Junior, acabou se tornando obra de referência para quem quer entender as transformações que o cinema sofreu desde sua manifestação clássica até o conceito de fluxo, que contaminou certa produção a partir da década de 1990. Partindo da ideia de mise em scène e da ótica da crítica francesa, em especial da consagrada revista Cahiers du Cinéma, o autor realiza um minucioso trabalho de garimpagem atrás de textos que deem conta deste conceito que, em última instância, molda aquilo de que os filmes se constituem. 
O livro parte de um resgate à origem do termo mise em scène, o qual se remete às artes cênicas. O metteur em scène era aquele responsável pela concepção global do espetáculo, ou seja, o agente incumbido da função de dispor os elementos cênicos em relação ao espaço-tempo. O cinema, enquanto aparato de registro e apresentação, perpetua este distanciamento entre plateia e espetáculo, de modo que acaba herdando o termo para si. A abrangência do mesmo, todavia, se torna ampla demais e assume uma identidade polimórfica e mutante. Luiz Carlos parte, então, de uma questão norteadora: o que é a mise em scène?

Abrindo mão de uma abordagem evolucionista dentro do cinema, mas assumindo as diferenças que cada proposta narrativa se propõe dentro desta arte, o autor estabelece um diálogo com nomes que marcaram a trajetória da Cahiers du Cinéma, onde mise em scène se torna elemento balizador e recorrente nos textos. A revista, criada em 1951, desenha, ao longo dos anos, embates em torno deste elemento essencial ao cinema. À época de seu lançamento, por exemplo, a oferta de filmes de então evidenciou a presença de duas tendências na crítica francesa: os hitchcock-hawksianos e os mac-mahonianos (ou mac-mahonistas). Os primeiros contavam com nomes como Rivette, Rohmer, Chabrol, Truffaut e Godard. A segunda turma era formada, entre outros, por Michel Mourlet, Pierre Rissient, Jacques Lourcelles e Jacques Serguine.

Os artigos eram produzidos, antes de qualquer coisa, por verdadeiros cinéfilos - muitos dos quais mais tarde se tornariam também cineastas. Estes críticos se questionavam sobre o que era fundamental em um filme, que força era essa capaz de tingir de verdade uma obra? Estaria ela relacionada à menor intromissão do autor, em um ideal bazaniano, onde o acesso ao real estaria mais desimpedido? Ou justamente na presença austera do realizador, imprimindo sua assinatura de maneira bem visível? Estas questões, de difíceis respostas, alimentaram muitos dos textos da época. E, longe de se chegar a um consenso, parecia haver certa concordância em torno de 
Otto Preminger, cujo cinema "se confunde com a definição mesma de mise em scène" (Oliveira Junior, 2013, p. 82).

A eclosão dos ditos cinemas novos do período pós-guerra, a partir da década de 1960, coloca em xeque não só certos preceitos e arranjos bem sedimentados pelo cinema hegemônico, de formato clássico, mas a própria ideia de mise em scène. Neste cenário difuso, “A pergunta deixa de ser 'o que é a mise em scène?' para se tornar 'onde está a mise em scène?' ou, nos casos mais agudos, 'para que serve a mise em scène?'" (Oliveira Junior, 2013, p. 87). Se a beleza antes residia na capacidade de se harmonizar os elementos captados, agora migrava para a desordem, para a subversão ou aposta no tempo, para o mundo que se desvela diante do olhar do cineasta.

A crise da mise em scène, desencadeada neste momento, gera uma série de filmes que operam no limiar de dois polos: a complexidade da encenação e a busca pela verdade na sua forma mais crua. Um panorama que foge de um estado estanque e dialético, algo que o autor faz questão de ressaltar ao abordar experiências de realizadores que transcendiam tal situação, como é o caso do casal Straub-Huillet.

Mas, se a passagem do clássico ao moderno foi responsável pela proliferação de tendências, tal cenário avançará a seu limite nas décadas de 1970 e 1980, quando Luiz Carlos identifica a presença marcante do maneirismo no cinema. Trata-se de filmes feitos por realizadores que têm a consciência de terem "chegado depois" (Oliveira Junior, 2013, p. 122). Época também assombrada pela suposta morte do cinema (o avanço do vídeo doméstico, o fim das salas de cinema de bairro, os primeiros passos da tecnologia digital), que faz com que o cinema se volte para si mesmo, seja por uma necessidade de reafirmação, seja por ode a outros tempos. Filmes oscilam entre "a sobrecarga e o retraimento" (Oliveira Junior, 2013, p. 123), em direção, quem sabem, a um estado de esgotamento. 
É neste momento que o autor chega ao conceito de cinema de fluxo. O termo, primeiramente apresentado pelo crítico Stéphane Bouquet, em 2002 (mas reincidente em outros artigos como os de Jean-Marc Lalanne e Olivier Joyard), tenta abarcar um conjunto de produções, oriundas de diferentes cinematografias, que compartilham um comportamento do olhar. Filmes que se moldam a partir da sensorialidade, forjando um conhecimento que foge ao engendramento racional e apela para a construção de sentido através da experiência corporal. Neste cenário, onde há a tendência para a errância, para a aleatoriedade, para o acidente, para o mundo que se apresenta na sua materialidade caótica, como pensar a ideia de mise em scène? É por isso que Oliveira Junior situa o cinema de fluxo como um divisor de águas neste processo histórico. Sublinhando a questão levantada por Jacques Aumont, em $O$ cinema e a encenação (2008), o autor sugere que talvez estejamos presenciando, hoje, o fim da mise em scène. Se não a aniquilação do conceito, pelo menos uma provocação para se repensar a abordagem do mesmo. O autor defende ainda a hipótese de que o cinema estaria, no fluxo, perto de sua mais perfeita forma barroca. Um cinema que crê no inacabamento, nas sensações, na força do movimento, na dissolução das formas.

O cinema de fluxo também se manifesta em um período em que cineastas são convidados a exporem suas obras em galerias de arte, em que se estabelece uma busca pela legitimação em meio a uma enxurrada do audiovisual. Desse modo, Luiz Carlos explica que o momento também possa se configurar como um retorno a um desejo inicial do cinema, o da apreensão do mundo em seu movimento natural; uma fascinação essencial do olhar. Assim, o plano se torna novamente espaço para este exercício, assumindo papel diferente do que a de um elemento funcional no todo fílmico. É aí que se observa o surgimento de "filmes-dispositivo" e "cineastas-artistas".

O livro de Luiz Carlos Oliveira Junior surge como ferramenta importante para a compreensão do cinema contemporâneo. Ao assumir o conceito de fluxo, aborda um 
tema ainda carente de bibliografia específica, sem, todavia, fundamentar sua análise em encaixotamentos enclausurantes. O texto é permeado por profícuas abordagens a filmes e cinematografias que justamente tensionam a ideia de mise em scène ao longo da história do cinema. A opção do autor por percorrer este caminho acompanhado pelo pensamento engendrado pela crítica acaba por transcender dogmatismos teóricos, nutrindo o texto com a paixão de verdadeiros devotos ao cinema.

Recebido em: 12 abr. 2014

Aceito em: 30 abr. 2014

Endereço do autor:

Emiliano Cunha <emilfc@gmail.com>

Pontifícia Universidade Católica do Rio Grande do Sul 